\title{
Behavioural adaptation: A review of adaptation to workplace heat exposure of kitchen workers with reference to gender differences in Durban
}

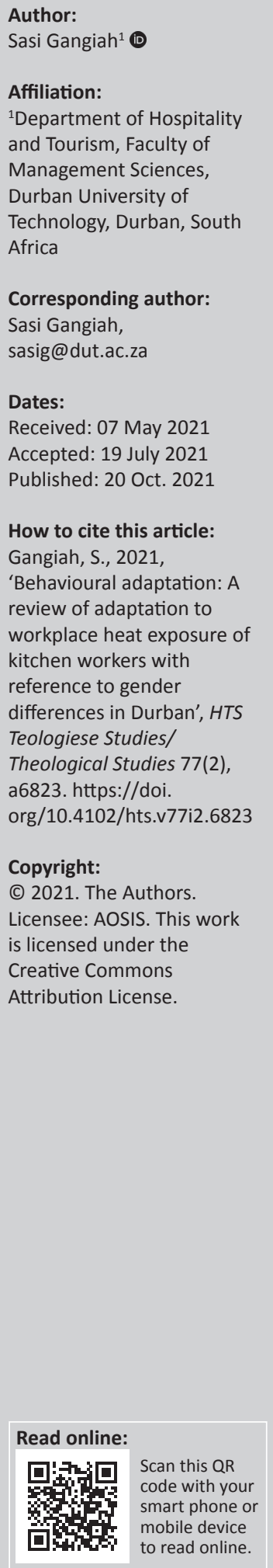

The article examines the gender disparities as women are at a greater risk to exertional heat illness that may go unreported in the industry, according to several reports. It is important to study the behavioural heat adaptations and prevalent behaviours for workers in order to understand the magnitude of the danger they face. Cooking is considered a safe occupation, but hazards certainly do exist and can represent a risk to the health and safety of the workers. Controls can be established to reduce the risk of illness. To attract and retain workers, the food service business must provide a good quality of life.

Contribution: The study suggests how female workers in the catering establishments can adjust their behaviour to improve their experience at work. Are women more vulnerable to environmental parameters? Christian theology provides women equal status with men (Kategile 2020), however there are traces of androcentric aspects within the Bible. Women's involvement in development is based on the theological premise that true development must have a holistic approach towards human development (Onwunta 2009). However, Sibani (2017) stated that the role of God or a creator of a religion, is always taken by a male and a woman's place is in the household. The article conducts a comprehensive analysis of the literature on the various behavioural adaptation mechanisms used by kitchen staff to cope with heat exposure at work. Thermal tolerance variations are becoming more pronounced because of ethnicity and cultural differences. Health interventions and enhanced work performance are important objectives of workplace safety. Regulated heat in the workplace can be factored into the theory concerning the relationship between gender differences and contextual components. This would increase female food service workers' understanding of thermal comfort, which is beneficial to productivity efficiency, worker satisfaction and well-being of workers.

Keywords: heat exposure; acclimatisation; heat illness; female worker; heat adaptation; behavioural adaptation.

\section{Introduction}

More than a decade ago, Chapanis (2004) claimed that modern ergonomics is not robust enough to deal with many significant differences found amongst the people of the earth. Ergonomics can roughly be defined as the study of people in their working environment. The goal is to eliminate discomfort and risk of injury because of work (University of North Carolina 2021). Individual variations in humans have a huge impact on comfort and should be wisely considered in the design of a building (Zhang \& De Dear 2019). This study aims to investigate the magnitude of gender differences in the environmental ergonomic parameters namely, heat, ventilation and humidity, amongst kitchen workers.

\section{Contextual background}

The 2030 Agenda for Sustainable Development, adopted by all United Nations Member States in 2015, has several Sustainable Development Goals (SDGs), which also includes gender equality and well-being. Inequality, according to Encyclopedia of Religion (2021), is androcentrism as seen in the Bible, which originates from a male monopoly on the cultural leadership and the shaping and transmission of culture.

The relationship between males and females in socio-cultural institutions is most often marred with inter alia domination and discrimination. The church is acclaimed as the arbiter of justice

Note: Special Collection: Gender Justice, Health and Human Development, sub-edited by Cheryl Potgieter (Durban University of Technology). 
and fairness, the refuge for oppressed people and victims of injustice. Yet, it accommodates gender domination and discrimination (Okoli 2019). Gender equity becomes imperative as Okeke (2011) posited that sustainable development requires the full participation of women at all levels. United Nations (2014) claimed that achieving gender equality is a central requirement of a just and sustainable world. Geneva College (2021) disseminated that restoration of the God's creation - the environment - is part of a Christian life.

This study examines that given the gender equality/ inequality status, do women kitchen workers react to kitchen environment in the same way as men? Does their well-being involve different behavioural adaptations to men? Does the discomfort level of men and women differ? Are women more vulnerable or sensitive to environmental parameters? Can the morphological differences amongst male and female workers affect heat adaptation? Do differences in the clothing typically worn by men and women affect adaptation to heat? Do make-up and hairstyles influence discomfort from heat? Earlier, Hignett (2001) criticised that there is very limited ergonomics information on female workers.

Ringstaff (2021) claimed that Proverb 31 on virtuous woman is not about being perfect but finding freedom from perfection and the confidence to live life with purpose. United Nations (2017) raised critical gender concerns in the advancement of the Sustainable Development Agenda, as women propel economic growth, protect the environment and advance social development, yet half of the population is left behind. Guzik (2021) claimed that Bible does allow a woman to work outside home, however, her priorities are home, husband, and bearing and raising of children.

Women, in particular, seem to be impacted more by climate change as it affects their ability to cope with the effects of climate change on their health (Hudspeth 2016). RuizCantero et al. (2007) argued that the bias from androcentrism affects new knowledge that lacks in research and scientific literature concerning issues related to women's occupational health.

\section{Workplace heat exposure}

Owing to under-reporting of heat disorders, the possible effects of occupational thermal experience are misjudged (Xiang et al. 2014). Kitchen workers in the hospitality industry are at risk of heat stress including grillers, fryers and bakers. According to Bible Hub (2021), Samuel 8:13 described that 'The king will take your daughters from you to be confectioner, cook and bake for him'. The Wet Bulb Globe Temperature (WBGT) (ISO 7243:1989) is widely prevalent in determining the direct Heat Stress Index that incorporates heat, humidity, airflow and heat radiation (Havenith \& Fiala 2011). At WBGT above $40^{\circ} \mathrm{C}$, it is challenging to perform any physical work (Parsons 2011). Hansen et al. (2018) reported symptoms of a worker looking pale, lethargic and distraught; experiencing headaches, muscle fatigue, exhaustion and fainting.

According to De Dear, Kim and Parkinson (2018), physiological, behavioural and psychological mechanisms such as acclimatisation, behavioural and environmental changes and occupant preferences are all involved in comfort adaptation. The authors add that claims of 'adaptive opportunity' refer to how well a built environment supports occupant comfort interventions.

\section{Kitchen worker risks}

Lerardi and Pavilonis (2020) warned about the dangers of heat-related illnesses (HRI) in a school kitchen. Continuous operation of and proximity to high heat-generating ovens and food warmers, inadequate or insufficient ventilation, a high worker density compared with the physical size of the kitchen space and a lack of adherence to a proper work/rest schedule because of constant meal demand are all factors that may contribute to levels of excessive heat stress in this setting.

\section{Kitchen heat generation}

Simone et al. (2013) found that the interior temperature in restaurant kitchens is unacceptable and climate zone influences thermal conditions in the kitchens. Where temperatures can be raised by machines, cooking equipment and inadequate ventilation, the kitchen staff is most at risk, with dry temperatures in the kitchen exceeding $30^{\circ} \mathrm{C}$ (Heinonen 1997). Increased heat in kitchens from fuels and cooking methods increase workers' risk. Zhao and Zhao (2018) added that Chinese cooking practices generate a large amount of heat. According to Fletcher (2006), there were no kitchens in the Old Testament. Food was prepared in the open in front of the tent, in city courtyards or in the shared living room.

Haruyama et al. (2010) reported that heat in liquefied petroleum gas (LPG) kitchens is much higher than in electric ones. Rabeiy (2018) reported that the WBGT index can reach $31.6^{\circ} \mathrm{C}$ in some bakeries, surpassing the threshold limit value of $28^{\circ} \mathrm{C}$. Gender disparities in physiological responses, as well as differences in men's and women's attire, may influence psychological responses to the moderate thermal climate encountered in everyday life (Yasuoka et al. 2015).

\section{Gender differences in thermal adaptation}

Historically, as early as the 1970s, Fanger (1970) observed that individual differences and several factors influenced thermal comfort such as age, gender and adaptation. Ravindra (2015) asserted that gender has the maximum impact on thermal comfort; gender influences an individual's ability to thermos-regulate (Farnell et al. 2008). 
Montazami and Lunn (2020) reported that females are more affected by poor indoor environmental quality than males. Women are more sensitive to departures from an ideal comfort setting and are more critical of the indoor thermal temperature (Zhang \& De Dear 2019). Indraganti (2020) found that women in Asia are more likely to be unhappy than males with their perceptions of thermal comfort and indoor air quality; a change in the design of personal controls for women can improve their contentment with environmental factors.

\section{Climate and lifestyle}

Lundgren and Holmér (2013) reported that climate change and global warming are exacerbating conditions in many tropical and sub-tropical areas with high temperatures and humidity. Durban has a humid sub-tropical coastal climate (Conradie 2012). According to Kjellstrom et al. (2014), during hot periods, the average temperature could rise by $2{ }^{\circ} \mathrm{C}$ to $4^{\circ} \mathrm{C}$, in most of South Africa; the occupational heat is changing from 'low risk' to 'moderate or high danger'.

Gangiah and Naidoo (2021) found that more than $98 \%$ of the male workers and $99.1 \%$ of the female workers were comfortable with the climate in Durban, and $98.4 \%$ of the male workers and $99.1 \%$ of the female workers like Durban climate. Almost $38 \%$ male workers and $62.6 \%$ female workers claimed that they did not maintain a comfortable lifestyle.

\section{Heat stress and physiology}

According to Goldfarb, Seo and Sinha (2019) gender-specific variability in physiological reactions can be related to differences in men and women's brain responses to acute stressors. Females may be more susceptible to stress as a result of these gender differences (Bangasser \& Wiersielis 2018). Male and female morphological differences in the ratio of body surface area to mass illustrate gender differences in heat loss thermo-effectors (Notley et al. 2017). Similarly, women may be more vulnerable to exertional heat illness (Alele et al. 2020). Lisman et al. (2014) reported that the association between gender and heat tolerance test (HTT) performance is controlled by anthropometric and fitness measurements.

Alarmingly, $42 \%$ of females were classified as heat intolerant in comparison to only $27 \%$ of males in the military.

Despite their higher fat content, females have lower skin temperatures at rest than males (Lundgren et al. 2013), but their body temperatures are higher during physical work (Haruyama et al. 2010). This is supported by Lan et al. (2008) who reported that women in China are more susceptible to temperature than humidity compared with men. Females' comfort temperature was marginally higher $\left(24.0^{\circ} \mathrm{C}\right)$ than males' $\left(23.2^{\circ} \mathrm{C}\right)$, as per Maykot et al. (2018). In the American Society of Heating, Refrigerating and Air-conditioning Engineers (ASHRAE) comfort zone, women felt a chill and were more uncomfortable than men. Female employees, according to Sümer (2020), fared better in terms of occupational temperature tolerance.
Interestingly, women experience the same thermal climate as being slightly cooler than men (Parsons 2002). According to Alshaikh and Alhefnawi (2020) females are less sensitive to high temperatures than males. This is supported by Kumar, Jain and Mathur (2020) who found that comfort temperatures of women were around $1.5^{\circ} \mathrm{C}$ higher than men's (Park, Loftness \& Aziz 2018). Women are more vulnerable to the effects of cold than men (Van Hoof et al. 2017).

Males with a factor loading of 0.780 cope with the heat better than females with other individual factors, showing that gender plays a vital role in coping with the heat (Gangiah \& Naidoo 2021). Lundgren et al. (2013) implied that men cope better with radiant heat generated by grillers and ovens. According to Devlin (2017), the variation in average basic metabolic rate (BMR) (women have a lower BMR than men) and body heat production between men and women explains why males and females have different comfort temperatures (BBC News Magazine 2015). Women's higher tolerance for humid heat is a physiological adaptation that is most likely because of their lower sweat levels (Xiang et al. 2014). This suggests that female workers can cope better with moist heat in the kitchen than male staff.

\section{Gender ratio}

Globally, women do $85 \%$ to $90 \%$ of the cooking, and comprise a significant part of the workforce in the food and restaurant industry (Niethammer 2020). Amongst the fast food workers in the United States of America (US), 51.2\% of them were women, whilst $43.5 \%$ were men (Zippia 2021), whereas $25.8 \%$ of women and $70.3 \%$ of men were chefs. Troitino (2020) highlighted the disheartening lack of leadership roles women hold in restaurants despite the central role they have traditionally held in kitchens. Almost $7 \%$ of restaurants in the US are led by women. The ratio of males to females was approximately 1:2 (36.3\%: 63.7\%) $(p<0.001)$ in this study. This is in concurrence with Logeswari and Mrunalini (2017) who reported that the majority of the workers in the hostel kitchens were female $(75 \%)$ and only $25 \%$ were male.

\section{Weight and body mass index}

The weight of South African kitchen workers was notably higher in the range from $42 \mathrm{~kg}$ to $157 \mathrm{~kg}$ with standard deviation of $15.46 \mathrm{~kg}$. A total of $64 \%$ of kitchen workers were female, and $50 \%$ of them were overweight. A total of $36 \%$ were males and $71 \%$ had normal weight. The body mass index (BMI) amongst the sampled kitchen workers varied from 18.70 (underweight) to 47.90 (severely obese) with a mean of 28.57, which indicates normal weight. In contrast, Haukka et al. (2012) reported that 15\% of Finnish female kitchen workers were obese and $33 \%$ were overweight. The role of gender was further amplified in cross-tabulation between the kitchen worker's gender and BMI that was found to be statistically significant. 
Guided by the definition of obesity where BMI $\geq 30$ (Hillis 2018), the present study found that a minority of $29.8 \%$ of kitchen workers had normal BMI, with the remaining workers being overweight to obese. BMI in the range of 20-25 is considered normal range; important to endure physically strenuous kitchen work, which affects acclimatisation. The risk of HRI increases with excess body fat (Bedno et al. 2014).

The logistic regression reveals that gender with a $\beta$ coefficient of 3.257 and variance inflation factor $(\mathrm{VIF})=1.209$ are factors affecting BMI of a kitchen worker. The association between variables across instruments informs that gender is closely associated with other individual factors, years of employment and type of kitchen. Exploratory factor analysis (EFA) further revealed a factor loading of $0.780,0.850$ and 0.554 for gender, race and fitness with factors influencing coping with kitchen heat and was categorised into component 1, Demographics. Contrarily, less than $6 \%(f=2)$ of head chefs strongly agreed that males cope better than females with kitchen heat.

\section{Clothing and gender}

Likewise, the importance of clothes in terms of thermal comfort cannot be overstated according to Fanger's (1970) comfort equation. Seasonal behavioural adaptation must be taken into account when assessing perceived thermal satisfaction (Park et al. 2018). Men and women's thermal discomfort is influenced by variations in clothing insulation.

During Biblical times, the commoner wore simple clothes that suited their environment and work. Both men and women wore a loose, woollen, robe-like cloak as an external apparel, secured at the waist with a band. A tunic or a coat was worn under the wrap (International Standard Bible Encyclopedia 2021). The difference between men and women's clothing was small, but distinctive. In addition, men regularly wore a turban to restrain their hair, and in some traditions, women wore a veil. However, there was a prohibition against wearing clothes woven of wool and linen together (Christian Bible Reference 2021).

Gender disparities may be attributed to variations in clothing insulation and metabolism (Park et al. 2018) with a substantial gap in thermal dissatisfaction between men and women. Hence, almost $39 \%$ of the kitchen workers in the present study were wearing a regulation T-shirt; even a house-coat for female chefs. A total of $50 \%$ of the kitchen managers claimed that staff complained with regard to humidity such as sweat not drying, wet uniforms and stickiness. In very hot periods, the human organism uses perspiration to maintain its temperature within proper physiological limits.

Singh et al. (2016) reported that male kitchen workers wear aprons and head-coverings in the kitchen over casual clothes. Females in India are mostly (99\%) dressed in loose-fitting Indian attire with much better scope for thermal adaptation (Indraganti, Ooka \& Rijal 2015). This is totally in contrast with Lundgren-Kownacki (2018), who claimed that female workers are more prone to heat stress because of the use of clothing that inhibits heat dissipation. Females were more vulnerable to heat stress due to the practice of wearing a protective shirt over traditional clothing at work, which increases the thermal discomfort. The researcher observed that $96.5 \%$ of the food service workers in the sampled kitchens wore long pants, except for 3.5\%. Golf shirts and formal shirts in kitchens were observed amongst $12 \%$ and $3.5 \%$ of kitchen workers, respectively.

The cross-tabulation between kitchen workers feeling comfortable working in chef's uniforms and the number of meals prepared in a single shift was found to be statistically significant; the two-sided p-value from Fisher's exact test was 0.045 . Only one chef had a wet uniform because of excessive sweating. New et al. (2020) proposed that staff should be advised to wear comfortable clothes made of natural fibres to facilitate adaptability to thermal comfort.

\section{Capacity for preventative behavioural control measures}

Behavioural control interventions aim to diminish exhaustion, maximise endurance and enable sustained activity during the workday. McCullough (1973) found that bio-cultural adaptation behaviour amongst the Yucatan avoids heat stroke and heat cramps when working in a hot environment. Lundgren-Kownacki (2018) reported that in Chennai (India), buttermilk is commonly consumed by workers, a traditional way of mitigating heat strain.

Self-pacing and rest breaks are traditional cultural practices including napping and pacing have been useful approaches for personnel to regulate and safeguard themselves from extreme heat in the past (Brake \& Bates 2002). The authors further suggest that the daytime difference in core body temperature, which is lower at nightfall, contributes to a lower risk of heat-related illness on the night shift, and therefore kitchen staff on the evening shift are exposed to lesser heat strain because of cooler evening temperatures.

Goldman (2014) suggested that human evolution can be influenced by traditions and cultural practices, play a dominant role in everyday survival in hot environments. Lundgren-Kownacki et al. (2018) argued that frequent use of air conditioning will lead to humans losing their physical and mental capacity to withstand heat, increasing susceptibility to rising urban temperatures. Gangiah and Naidoo (2021) reported that only 3.5\% male workers and $7.2 \%$ female workers use an air-conditioner in their residence and $11.5 \%$ male workers and $7.9 \%$ female workers drive a car to work. However, $44.3 \%$ male workers and $44.8 \%$ female workers complained that the cooling sources in their restaurant kitchens were inadequate. Around $64 \%$ females do not use make up whilst working in restaurant kitchens to improve thermal comfort. 
Nonetheless, as various socioeconomic groups have different capacities for responding to growing crises, increased heat affects people unequally (Lundgren-Kownacki et al. 2018). Behavioural adaptations to hot weather, according to Kenny et al. (2019), also play a part in reducing a person's vulnerability to indoor heat stress.

\section{Behavioural adaptation}

Humans have developed habitat-specific cultural heat adaptations (Boyd, Richerson \& Henrich 2011). Culture and genetics are becoming profoundly intertwined, with each affecting the natural progression of the other, resulting in a phenomenon known as 'gene-culture co-evolution' (Goldman 2014). As per Hellwig et al. (2020), thermosregulation may be a behavioural response because comfort/ distress perception triggers behavioural adaptation.

Van Hoof et al. (2017) found that the initial step is a behavioural action followed by adjustment of thermal environments such as reducing clothing layer, rest or open windows. Other adjustments include minimising physical activity, remaining indoors, wearing light, cool clothing, increasing liquid intake and utilising an air conditioner.

Behavioural modification amongst people of lower socioeconomic status is moderated by their living conditions, their sub-standard housing with insufficient ventilation and air-conditioning (Hansen et al. 2013), and as these workers cannot cool their bodies adequately at night, they are at an increased risk (Frimpong 2015). Environmental changes that cause irregular events, long durations or a lack of cooling at night, according to Sheridan and Dixon (2017), may alter the nature of heat impacts. Schweiker et al. (2017) are convinced that behavioural adaptation is relevant in both mechanically and non-mechanically cooled workspaces.

Reactive behavioural adjustment to heat adaptation dominates studies seeking improvement in conditions that impact heat illness (Figure 1). Whilst there are proactive practices for human heat adaptation in the workplace, it is

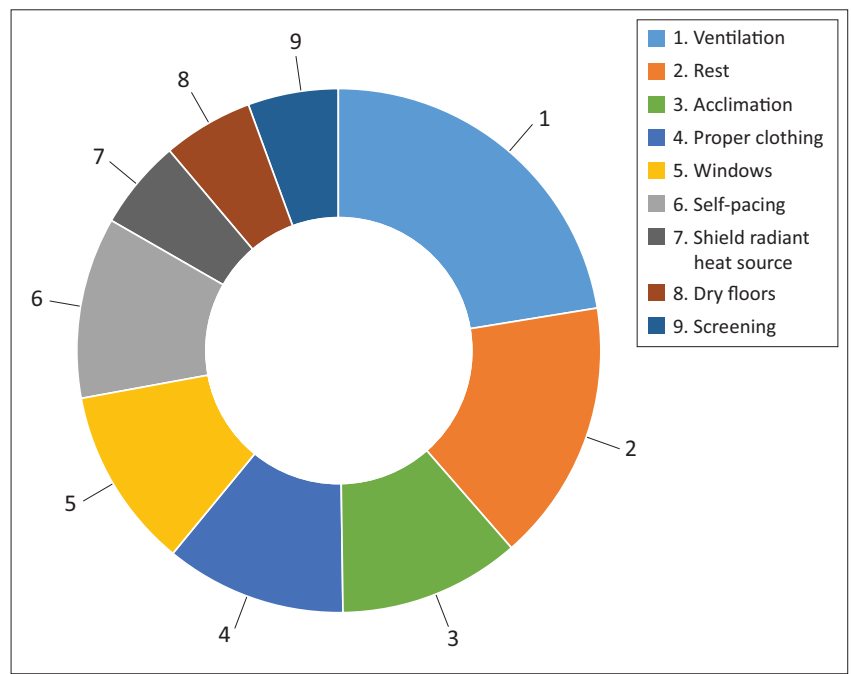

FIGURE 1: Amelioration of conditions influencing heat illness in kitchens. sparsely mentioned in literature. However, Bates and Schneider (2008) observed mandatory hydration and thermal work limits in the workplace, a condition imposed on kitchen workers would suitably assist in keeping their well-being. A working knowledge of hydration and selfpacing assists in the effective assessment of thermal work limit (Kapanowski 2018).

Two findings strongly support preventative dehydration out of the seven reactive behavioural adjustment studies analysed in this study (Table 1). Preventative dehydration seeks to replace water timeously. Drinking cold water clearly advances the cooling of the body and prevents dehydration (Logeswari \& Mrunalini 2017; Totsky 2006). The authors further emphasise worker acclimatisation to heat and the use of appropriate clothing to ensure thermal comfort. Totsky (2006) and Matsuzuki et al. (2011) proposed pacing and rest to decrease thermal discomfort.

Drinking large amounts of water can cause frequent urination, necessitating adequate toilet facilities for employees (Biggs, Paterson \& Maunder 2011). Kitchen workers are often more likely to skip regular toilet visits for the reasons mentioned above, as well as for hygiene reasons, resulting in dehydration. This is likely to increase heat strain amongst cooks, bakers and dishwashers.

Opening windows where feasible, improving air circulation by using fans, installing sufficient extractors for fumes and gases, air-conditioning work areas and restrooms to reduce ambient temperature and thermal load on workers as shown in Table 1 are some of the modifications when affected at work areas can help minimise heat (Unison 2014). Behavioural modifications include cooking on back burners that further removes cooking emissions, so it should always be used first, effectively reducing humidity (Singer \& Stratton 2014).

To efficiently treat heat-related illness, some authors suggest educational initiatives and worker awareness (Table 1). Haruyama et al. (2010) discovered that heat stress could be minimised in work areas with high heat and humidity, such as commercial kitchens, by simply maintaining dry floors. Researchers in the US and China have created a heat-rejecting film that can reflect up to $70 \%$ of the heat emitted by sunlight in a building's windows (Chu 2018). This film, which is embedded with tiny thermochromic particles, can be used to cover exterior-facing windows to cut air-conditioning costs by $10 \%$. To minimise heat in kitchens, kitchen windows can be covered with film.

In their analysis, Gangiah and Naidoo (2021) discovered that all kitchens had cooling devices in addition to extractors to minimise humid heat. Fewer air conditioners and industrial fans were identified by significantly more respondents ( $p$ 0.05). Head chefs and kitchen managers claim to have cleaned the extractors (44\%) to minimise humidity in kitchens, whilst $41 \%$ say humidity is not a problem. To reduce humidity, nearly 
TABLE 1: Behavioural modifications amongst kitchen workers.

\begin{tabular}{|c|c|c|c|c|c|c|}
\hline Source & $\begin{array}{l}\text { Location of } \\
\text { study }\end{array}$ & $\begin{array}{l}\text { Type of } \\
\text { workplace / } \\
\text { occupation }\end{array}$ & $\begin{array}{l}\text { Heat generating factors: Temperature } \\
\text { at workplace/environment, body heat } \\
\text { and PPE }\end{array}$ & $\begin{array}{l}\text { Danger to worker: Effect } \\
\text { on worker physiology/work }\end{array}$ & $\begin{array}{l}\text { Adopted } \\
\text { adaptation }\end{array}$ & Adaptation recommended \\
\hline $\begin{array}{l}\text { Eagles \& } \\
\text { Stedmon } \\
2004\end{array}$ & London, UK & Kitchen workers & $\begin{array}{l}\text { Dry bulb temperature } 22.8^{\circ} \mathrm{C}\left(73.0^{\circ} \mathrm{F}\right) \text {. } \\
\text { Heat from cookers, stoves, grillers, } \\
\text { humidity from water usage }\end{array}$ & 0 & 0 & $\begin{array}{l}\text { Open kitchen windows, install } \\
\text { more extractor fans and } \\
\text { ventilation hoods }\end{array}$ \\
\hline Totsky (2006) & Michigan & $\begin{array}{l}\text { Chefs and } \\
\text { dishwashers }\end{array}$ & $\begin{array}{l}\text { WBGT } 25.5^{\circ} \mathrm{C} \text { to } 35.7^{\circ} \mathrm{C}\left(77.9^{\circ} \mathrm{F}-96.26^{\circ} \mathrm{F}\right) \\
\text { Outside temperature } 35.5^{\circ} \mathrm{C}\left(95.9^{\circ} \mathrm{F}\right)\end{array}$ & $\begin{array}{l}\text { Heat exhaustion, heat } \\
\text { fatigue }\end{array}$ & $\begin{array}{l}\text { Circulating } \\
\text { fans, drink } \\
\text { water, } \\
\text { acclimated } \\
\text { workers }\end{array}$ & $\begin{array}{l}\text { Preplacement screening of } \\
\text { susceptible workers, monitor } \\
\text { cool drinking water-1 cup every } \\
20 \text { min, use proper clothing, rest } \\
\text { in cool place, provide shielding } \\
\text { from radiant heat, adequate } \\
\text { ventilation, air conditioner in } \\
\text { kitchen, training on symptoms of } \\
\text { heat stress, pacing. }\end{array}$ \\
\hline $\begin{array}{l}\text { Haruyama } \\
\text { et al. } 2010\end{array}$ & Japan & Kitchen workers & MRT up to $36.4^{\circ} \mathrm{C}\left(97.52^{\circ} \mathrm{F}\right)$ & Thermal strain & 0 & $\begin{array}{l}\text { Dry floors reduce humidity in } \\
\text { kitchen }\end{array}$ \\
\hline $\begin{array}{l}\text { Matsuzuki } \\
\text { et al. } 2011\end{array}$ & Japan & Kitchen workers & $\begin{array}{l}\text { WBGT } 27.5^{\circ} \mathrm{C}\left(81.5^{\circ} \mathrm{F}\right) \text { Dry bulb } 22.8^{\circ} \mathrm{C} \\
\left(73.04{ }^{\circ} \mathrm{F}\right) . \text { Heat from cookers, stoves, } \\
\text { grillers, humidity from water usage }\end{array}$ & $\begin{array}{l}\text { Heat stress: Fatigue and } \\
\text { dehydration kitchen workers } \\
\text { take break from work }\end{array}$ & 0 & $\begin{array}{l}\text { Recommendation: Rest and } \\
\text { pacing }\end{array}$ \\
\hline Li et al. 2012 & China & Kitchen workers & $\begin{array}{l}\text { Dry bulb varied from } 18.5^{\circ} \mathrm{C} \text { to } 54.0^{\circ} \mathrm{C} \\
\left(65.3^{\circ} \mathrm{F}-129.2^{\circ} \mathrm{F}\right) \text { in different kitchens. } \\
\text { Heat from cookers, stoves, grillers, } \\
\text { humidity from water usage }\end{array}$ & $\begin{array}{l}\text { Thermal dissatisfaction } \\
\text { decreased productivity }\end{array}$ & 0 & $\begin{array}{l}\text { Improved ventilation system in } \\
\text { naturally ventilated kitchen }\end{array}$ \\
\hline $\begin{array}{l}\text { Simone et al. } \\
2013\end{array}$ & $\begin{array}{l}\text { USA-different } \\
\text { cities in } \\
\text { summer and } \\
\text { winter }\end{array}$ & Kitchen workers & $\begin{array}{l}\text { Dry bulb up to } 41.2^{\circ} \mathrm{C}\left(106.01^{\circ} \mathrm{F}\right) \text { Heat } \\
\text { from cookers, stoves, grillers, humidity } \\
\text { from water usage }\end{array}$ & Uncomfortable environment & - & Opening windows \\
\hline Khare 2014 & $\begin{array}{l}\text { Bangalore, } \\
\text { India } 2014\end{array}$ & Kitchen workers & $\begin{array}{l}28.5^{\circ} \mathrm{C}\left(83.3^{\circ} \mathrm{F}\right) \text { with } 65 \%-72 \% \\
\text { humidity. }\end{array}$ & Heat stress & 0 & $\begin{array}{l}\text { Provide } \\
\text { good ventilation and comfort }\end{array}$ \\
\hline $\begin{array}{l}\text { Logeswari \& } \\
\text { Mrunalini } \\
2017\end{array}$ & $\begin{array}{l}\text { Telengana, } \\
\text { India }\end{array}$ & Kitchen workers & $\begin{array}{l}\text { WBGT } 29.1^{\circ} \mathrm{C}\left(84.2^{\circ} \mathrm{F}\right) \\
\text { Mean ear temperature } 39^{\circ} \mathrm{C} \text {, higher } \\
\text { than WHO permissible limit }\end{array}$ & Heat stress & 0 & $\begin{array}{l}\text { Training on heat stress, improve } \\
\text { ventilation, loose fitting clothing, } \\
\text { adequate drinking water-5L/day, } \\
\text { breaks between work. }\end{array}$ \\
\hline $\begin{array}{l}\text { Lelardi \& } \\
\text { Pavalonis } \\
2020\end{array}$ & $\begin{array}{l}\text { New York } \\
\text { City, USA }\end{array}$ & Kitchen workers & $\begin{array}{l}\text { WBGT } 25.0^{\circ} \mathrm{C} \pm 2^{\circ} \mathrm{C}\left(77^{\circ} \mathrm{F}\right) \\
80 \% \text { of schools surpassed maximum for } \\
\text { the heavy work-rate }\end{array}$ & Heat stress & 0 & $\begin{array}{l}\text { Work and rest schedules, } \\
\text { engineering and administrative } \\
\text { controls }\end{array}$ \\
\hline
\end{tabular}

PPE, personal protective equipment; 0 , no data reported; $\mathrm{MRT}$, mean radiant temperature; WBGT, wet bulb globe temperature.

$30 \%$ of the kitchen managers opened windows and doors and $35.3 \%$ mounted fans.

Gangiah and Naidoo (2021) account for kitchen workers who stand near the air-conditioner or fan; step out of the kitchen, move to the back door where airflow helps cope with stuffiness and heat and take a short break. The most common behavioural adaptation by workers was to drink cold liquid (94\%). Behavioural modification to cope with humidity includes the use of fans and air-conditioners by kitchen workers. A total of $35 \%$ of head chefs reported that $8.8 \%$ of workers took a short break or stepped outside to get respite from the heat. A total of $47 \%$ of head chefs strongly agreed that work experience played a strong role in coping with the heat, followed by race (37.5\%). Fitness and body weight were also considered important with $20.6 \%$ and $14.7 \%$ of head chefs, respectively.

Other strategies used by kitchen workers included going towards a cooler, sitting near the cooler, putting head inside the chiller, keeping the back door open and pouring water on their heads. Kumar et al. (2020) reported that students indulge in interactive adaptation such as opening windows, doors, fans, changing their activity to rest or take a break from work. Students further drink hot or cold beverages, move to some airy place or walk indoors or outdoors to make themselves comfortable during uncomfortable conditions.

These behaviours resonate with a study by Indraganti et al. (2015) that office workers adapt to summer and monsoon (humid) conditions by staying in airy places, drinking cold/ hot beverages, and changing their posture. Occupants also avoid direct sunlight, rest, rinse their face and hands and avoid heat sources. Workers' fluid and electrolyte supplementation, long rest breaks and sitting under fans are all listed by Balakrishnan et al. (2010). If the workplace is not dangerously hot, Ballman (2012) suggested that using fans, drinking plenty of water and putting a cool wet cloth on the forehead periodically will help cope with heat stress. Several chefs claimed that in Norwich, cool baby wipes are used to wipe heads. Drinking plenty of water helps to get through the heat as the temperature at a bakery can reach $37.8^{\circ} \mathrm{C}$.

To quench their thirst, nearly a quarter of the workers, who were studied, rendered cold lemonade. There is no clear legislation about humidity, according to the University of Birmingham Health and Safety Fact File (2006). Workers are allowed to take extra breaks, are provided with cold drinks or the dress code could be relaxed. Even if the temperature is high, health and safety measures, such as wearing the appropriate protective personal equipment, must not be overlooked. Kitchens with induction cooktops provide greater comfort to chefs than those with LPG cooktops (Wong et al. 2011). Relevant behaviours and activities may also be targeted by education and by creating awareness (World Health Organization 2020).

\section{Prospective designs to improve conditions that impact heat illness}

Creating a win-win situation for workers' health and work performance is the way forward. On the one hand, workers' 
health is at risk, and on the other hand, the researcher believes that there is no clear provision in South African legislation for employees to reduce risk exposure. In the US, a countrywide awareness educates workers and employers about the dangers of working in the heat and preventing illness (National Institute of Occupational Safety and Health [NIOSH] 2015).

The pursuance of protocols of the hospitality sector to protect workers from the heat exposure has compelled some of the foregoing choices in design and management. This inertia could be attributable to policy gaps or simply the failure of management to plan for long term. Regrettably, the researcher feels that collective responsibility for safety and human health foster vague duty for individual action. When it comes to safeguarding people from high heat, investigators, representatives, state and city council members and officials, all must be vigilant (Sheridan \& Dixon 2017).

\section{Conclusion}

This article conducts a comprehensive analysis of the literature on the various behavioural adaptation mechanisms used by kitchen staff to cope with heat exposure at work. The discomfort levels of men and women vary as women are more sensitive to dry heat and cold. Clothing worn by women, their make-up and hairstyles influence discomfort from heat, highlighting ergonomics data on female workers. Comparative studies have not been performed to establish which behavioural measure is superior to others. It is clearly observable that kitchen workers were provided with inadequate measures to reduce heat strain.

\section{Acknowledgements Competing interests}

The author declares that they have no financial or personal relationships that may have inappropriately influenced them in writing this article.

\section{Author's contributions}

S.G. is the sole author of this article.

\section{Ethical considerations}

Ethical clearance to conduct this study was obtained by the Faculty Research Committee, Durban University of Technology.

\section{Funding information}

This research received no specific grant from any funding agency in the public, commercial or not-for-profit sectors.

\section{Data availability}

The data presented in this article are present within the article.

\section{Disclaimer}

The views and opinions expressed in this article are those of the author and do not necessarily reflect the official policy or position of any affiliated agency of the author.

\section{References}

Alele, F., Malau-Aduli, B., Malau-Aduli, A. \& Crowe, M., 2020, 'Systematic review of gender differences in the epidemiology and risk factors of exertional heat illness and heat tolerance in the armed forces', BMJ Open 10(4), e031825. https://doi. org/10.1136/bmjopen-2019-031825

Alshaikh, A.M. \& Alhefnawi, M.A.M., 2020, 'Thermal comfort and gender: A practical study in the eastern province of Saudi Arabia', in S. Roaf, F. Nicol \& W. Finlayson (eds.), pp. 381-392, Resilient Comfort Proceedings, Ecohouse Initiative Ltd, Windsor, 16-19 April.

Balakrishnan, K., Ramalingam, A., Dasu, V., Chinnadurai Stephen, J., Raj Sivaperumal, M., Kumarasamy, D., Mukhopadhyay, K. et al., 2010, 'Case studies on heat stress related perceptions in different industrial sectors in Southern India', Global Health Action 3(1), 5635. https://doi.org/10.3402/gha.v3i0.5635

Ballman, D., 2012, Screw you guys, I am going home, viewed n.d., from http:// employeeatty.blogspot.com/2012/08/my-office-air-conditioning-broke-in.html.

Bangasser, D.A. \& Wiersielis, K.R., 2018, 'Sex differences in stress responses: A critical role for corticotropin-releasing factor', Hormones 17, 5-13. https://doi. org/10.1007/s42000-018-0002-z

Bates, G.P. \& Schneider, J., 2008, 'Hydration status and physiological workload of UAE construction workers: A prospective longitudinal observational study', Journal of Occupational Medicine and Toxicology 3, 21. https://doi. org/10.1186/1745-6673-3-21

BBC News Magazine, 2015, Air-conditioning: Why might women feel temperature differently from men?, viewed n.d., from https://www.bbc.com/news/ differently from magazine-33760845.
m.

Bedno, S., Urban, N., Boivin, M. \& Cowan, D., 2014, 'Fitness, obesity and risk of heat illness among army trainees', Occupational Medicine 64(6), 461-467. https://doi. org/110.1093/occmed/kqu062

Bible Hub, 2021, 1 Samuel 8:13 Commentaries, viewed n.d., from https://biblehub. com/1_samuel/8-13.htm.

Biggs, C., Paterson, M. \& Maunder, E., 2011, 'Hydration status of South African forestry workers harvesting trees in autumn and winter', Annals of Occupational Hygiene $55,6-15$.

Boyd, R., Richerson, P.J. \& Henrich, J., 2011, 'The cultural niche: Why social learning is essential for human adaptation', Proceedings of the National Academy of Sciences 108, 10918-10925. https://doi.org/10.1073/pnas.1100290108

Brake, D.J. \& Bates, G.P., 2002, 'Deep body core temperatures in industrial workers under thermal stress', Journal of Occupational and Environmental Medicine 44, 125-135. https://doi.org/10.1097/00043764-200202000-00007

Chapanis, A., 2004, National and cultural variables in ergonomics. Cultural Ergonomics, Emerald Group Publishing Limited, Amsterdam.

Christian Bible Reference, 2021, What does the Bible say about proper dress?, viewed n.d., from https://www.christianbiblereference.org/faq_dress.htm.

Chu, J., 2018, See-through film rejects 70 percent of incoming solar heat, viewed n.d., from http://news.mit.edu/2018/see-through-film-rejects-incoming-solar-heat-1108.

Conradie, D.C.U., 2012, 'South Africa's climatic zones: Today, tomorrow', International Green Building Conference and Exhibition, Sandton, South Africa.

De Dear, R., Kim, J. \& Parkinson, T., 2018, 'Residential adaptive comfort in a humid subtropical climate-Sydney Australia', Energy and Buildings 158, 1296-1305.

Devlin, H., 2017, Why women secretly turn up the heating?, The Guardian, viewed n.d., from https://www.theguardian.com/science/shortcuts/2017/oct/11/whywomen-sewcretly-turn-up-the-heating.

Encyclopedia of Religion, 2021, Androcentrism, viewed n.d, from https://womrel. sitehost.iu.edu/REL301\%20Women/Ruether_Androcentrism.pdf.

Fanger, P.O., 1970, Thermal comfort: Analysis and applications in environmental engineering, Danish Technical Press, Copenhagen.

Farnell, G.S., Pierce, K.E., Collinsworth, T.A., Murray, L.K., Demes, R.N., JuvancicHeltzel, J.A. et al., 2008, 'The influence of ethnicity on thermoregulation after acute cold exposure', Wilderness \& Environmental Medicine 19, 238-244.

Frimpong, K., 2015, 'An appraisal of experiences of climate change and adaptive response to heat stress by farmers in rural Ghana', PhD thesis, Edith Cowan University.

Fletcher, E., 2006, Cooking in the ancient world of the Bible, viewed n.d., from https:// www.womeninthebible.net/bible_daily_life/cooking_ancient/

Gangiah, S. \& Naidoo, K.M., 2021, 'An exploration of environmental ergonomics: A case of restaurant kitchens in Durban', PhD thesis, Durban University of Technology.

Geneva College, 2021, Christians and the environment, viewed n.d., from https:// www.geneva.edu/community/environmental-stewardship/why_care

Goldfarb, E.V., Seo, D. \& Sinha, R. 2019, 'Sex differences in neural stress responses and correlation with subjective stress and stress regulation', Neurobiology of Stress 11. https://doi.org/10.1016/j.ynstr.2019.100177 
Goldman, G.J., 2014, How human culture influences our genetics, viewed n.d, from https://www.bbc.com/future/article/20140410-can-we-drive-our-ownevolution.

Guzik, D., 2021, Does the Bible allow women to work outside the home? Enduring Word viewed n.d., from https://enduringword.com/does-the-bible-allow-women-towork-outside-the-home-live-qa-for-february-18-2021/.

Hansen, A., Bi, L., Saniotis, A. \& Nitschke, M., 2013, 'Vulnerability to extreme heat and climate change: Is ethnicity a factor?', Global Health Action 6. https://doi. org/10.3402/gha.v6i0.21364

Hansen, A., Pisaniello, D., Varghese, B., Rowett, S., Hanson-Easey, S., Bi, P. \& Nitschke, M., 2018, 'What can we learn about workplace heat stress management from safety regulator complaints database?', International Journal of Environmento Research and Public Health 15, 459.

Haruyama, Y., Muto, T., Matsuzuki, H., Ito, A., Tomita, S., Muto, S. et al., 2010 'Evaluation of subjective thermal strain in different kitchen working environments using subjective judgment scales', Industrial Health 48 135-144. https://doi. org/10.2486/indhealth.48.135

Haukka, E., Ojajärvi, A., Takala, E.-P., Viikari-Juntura, E. \& Leino-Arjas, P., 2012, 'Physical workload, leisure-time physical activity, obesity and smoking as predictors of multisite musculoskeletal pain: A 2-year prospective study of kitchen workers', Occupational and Environmental Medicine 69(7), 485-492. https://doi. org/10.1136/oemed-2011-100453

Havenith, G. \& Fiala, D., 2011, 'Thermal indices and thermophysiological modeling for heat stress', Comprehensive Physiology 6 255-302.

Heinonen, J., 1997, Thermal conditions in commercial kitchens, viewed n.d, from https://www.aivc.org/sites/default/files/airbase_12100.pdf.

Hellwig, R.T., Despoina, T., Schweiker, M., Choi, J.-H., Lee, J.M., Mora, R. et al., 2020 'Guideline to bridge the gap between adaptive thermal comfort theory and building design and operation practice', in Roaf, S., Nicol, F. \& Finlayson, W. (eds.), Windosor Conference Proceedings, Ecohouse Initiative Ltd., Resilient Comfort, 16-19 April, pp. 529-545.

Hignett, S., 2001, 'Using qualitative methodology in ergonomics: Theoretical background and practical examples', PhD thesis, University of Nottingham.

Hillis, J., 2018, 'Using qualitative methodology in ergonomics: Theoretical background and practical examples', PhD thesis, University of Nottingham.

Hudspeth, E.F., 2016, 'Climate change and gender', in N.A. Naples (ed.), The Wiley Blackwell Encyclopedia of Gender and Sexuality Studies, Wiley-Blackwell, Hoboken, NJ.

Indraganti, M., 2020, 'Differences in thermal comfort and satisfaction in offices based on gender', in S. Roaf, F. Nicol \& W. Finlayson (eds.), pp. 829-841, Resilient Comfort Proceedings, Ecohouse Initiative Ltd, Windsor, 16-19 April.

Indraganti, M., Ooka, R. \& Rijal, H.B., 2015, 'Thermal comfort in offices in India: Behavioral adaptation and the effect of age and gender', Energy and Buildings 103, 284-295. https://doi.org/10.1016/j.enbuild.2015.05.042

International Standard Bible Encyclopedia, 2021, Dress, viewed n.d., from https:// archive.is/VUCuO\#selection-96.0-3048.0.

Kandasamy, I. \& Ancheri, S., 2009, 'Hotel employees' expectations of QWL: A qualitative study', International Journal of Hospitality Management 28(3), 328-337. https://doi.org/10.1016/j.ijhm.2008.11.003

Kapanowski, D.L., 2018, 'Validation of the Thermal Work Limit (TWL) against known heat stress exposures', Master's thesis, University of South Florida.

Kategile, M.L., 2020, 'The Bible and gender equality in church leadership in Tanzania', Stellenbosch Theological Journal 6(1), 41-54. https://doi.org/10.17570/stj.2020. v6n1.a03

Kenny, G.P., Flouris, A.D., Yagouti, A. \& Notley, S.R., 2019, 'Towards establishing evidence-based guidelines on maximum indoor temperatures during hot weather in temperate continental climates', Temperature 6(1), 11-36. https://doi.org/10 in temperate continental climates

Khare, T., 2014, 'Work assessment of small-scale restaurant workers and their enterprising ability', The Asian Review of Civil Engineering 3(1), 18-22.

Kjellstrom, T., Lemke, B., Hyatt, O. \& Otto, M., 2014, 'Climate change and occupational health: A South African perspective', South African Medical Journal 104(8), 1-5. https://doi.org/10.7196/SAMJ.8646

Kumar, S., Jain, N. \& Mathur, J., 2020, 'Experimental investigation of ISHRAE IEQ Standard focusing on implementation aspects through', Indoor Environmental Quality: Select Proceedings of the 1st ACIEQ 60, 167-182. https://doi. org/10.1007/978-981-15-1334-3_17

Lan, L., Lian, Z., Liu, W. \& Liu, Y., 2008, 'Investigation of gender difference in thermal comfort for Chinese people', European Journal of Applied Physiology 102, 471-480. https://doi.org/10.1007/s00421-007-0609-2

Lerardi, A.M. \& Pavilonis, B., 2020, 'Heat stress risk among New York City public school kitchen workers: A quantitative exposure assessment', Journal of Occupational and Environmental Hygiene 17(7-8), 353-363. https://doi.org/10.1080/1545962 4.2020 .1776300

Lisman, P., Kazman, J.B., O'Connor, F. G., Heled, Y. \& Deuster, P.A., 2014, 'Heat tolerance testing: Association between heat intolerance and anthropometric and fitness measurements', Military Medicine 179(11). https://doi.org/1339-1346. 10.7205/MILMED-D-14-00169

Logeswari, S. \& Mrunalini, A., 2017, 'Heat stress among large kitchen workers in hostel', International Journal of Pure and Applied Bioscience 5, 607-610. https:// doi.org/10.18782/2320-7051.5177

Lundgren-Kownacki, K., 2018, 'The heat is on: evaluation of workplace heat stress under a changing climate', PhD thesis, Lund University.
Lundgren-Kownacki, K., Hornyanszky, E. D., Chu, T.A., Olsson, J.A. \& Becker, P., 2018, 'Challenges of using air conditioning in an increasingly hot climate', Internationa Journal of Biometeorology 62, 401-412. https://doi.org/10.1007/s00484-017Journal

Lundgren, K. \& Holmér, I., 2013, 'Climate change and occupational health-populations exposed and the sustainability of methods to avoid excessive heat in workplaces', in J.D. Cotter, J.E.L. Samuel \& T. Mündel (ed.), 15th International Conference on Environmental Ergonomics, pp. 20-21, 11-15 February 2013, Queenstown.

Lundgren, K., Kuklane, K., Gao, C. \& Holmer, I., 2013, 'Effects of heat stress on working populations when facing climate change', Industrial Health 51, 3-15. https://doi. org/10.2486/indhealth.2012-0089

Matsuzuki, H., Ito, A., Ayabe, M., Haruyama, Y., Tomita, S., Katamoto, S. et al., 2011, 'The effects of work environments on thermal strain on workers in commercial kitchens', Industrial Health 49, 605-613. https://doi.org/10.2486/indhealth.MS1219

Maykot, J.K., Rupp, R.F. \& Ghisi, E., 2018, 'Assessment of gender on requirements for thermal comfort in office buildings located in the Brazilian humid subtropical climate', Energy and Buildings 158, 1170-1183. https://doi.org/10.1016/j. enbuild.2017.11.036

Mccullough, J.M., 1973, 'Human ecology, heat adaptation, and belief systems: The hot-cold syndrome of Yucatan', Journal of Anthropological Research 29, 32-36. https://doi.org/10.1086/jar.29.1.3629623

Montazami, A. \& Lunn, C., 2020, Office workers' stress level; the impact of IEQ, control and personal factors, in S. Roaf, F. Nicol \& W. Finlayson (eds.), Resilient Comfort, Windsor.

National Institute of Occupational Safety and Health (NIOSH), 2015, Indoor Environmental Quality, Center for Disease Control and Prevention, viewed n.d., from http://www.cdc.gov/niosh/topics/indoorenv/.

New, K., Friday, A., Gormally, A., Tyler, A. \& Hazas, M., 2020, 'Exploring current and future thermal comfort practices in shared workspaces', S. Roaf, F. Nicol \& W. Finlayson (eds.), Proceedings of the 11th Windsor Conference, Resilient Comfort, Ecohouse Initiative Ltd., Windsor, 16-19 April, pp. 785-801.

Niethammer, C., 2020, Finding a recipe for a more equitable food and restaurant industry, viewed n.d., from https://www.forbes.com/sites/carmenniethammer/2020/09/27/ finding-a-recipe-for-a-more-equitable-food-and-restaurantindustry/?sh=7cb945cf4325.

Notley, S.R., Park, J., Tagami, K., Ohnishi, N. \& Taylor N.A., 2017, 'Variations in body morphology explain sex differences in thermoeffector function during compensable heat stress', Experimental Physiology, 102(5), 545-562. https://doi. org/10.1113/EP086112

Okeke, F., 2011, 'Towards maintaining gender equity for sustainable development in Nigeria', Journal of Internafional Gender Studies 7, 134-158.

Okoli, M., 2019, 'Doctoral research supervision experiences of business education students in Nigeria', Doctorate, University of KwaZulu-Natal.

Onwunta, I.E., 2009, Gender stereotyping in church and community: A Nigerian feminine perspective, Stellenbosch University.

Park, J., Loftness, V. \& Aziz, A., 2018, 'Post-occupancy evaluation and IEQ measurements from 64 office buildings: critical factors and thresholds for user satisfaction on thermal quality', Buildings 8(11), 1-24. https://doi.org/10.3390/ buildings 8110156

Parsons, K.C., 2002, 'The effects of gender, acclimation state, the opportunity to adjust clothing and physical disability on requirements for thermal comfort', Energy and Buildings 34(6), 593-599. https://doi.org/10.1016/S0378-7788(02)00009-9

Parsons, K.C., 2011, 'Assessment of heat stress and heat stress indices', Encyclopedia of Occupational Health and Safety, viewed n.d., from http://www. iloencyclopaedia.org/part-vi-16255/heat-and-cold/76-42-heat-and-cold/ assessment-of-heat-stress-and-heat-stress-indicies.

Rabeiy, R., 2018, 'Evaluation of indoor heat stress on workers of bakeries at Assiut City, Egypt', International Journal of Environmental Science and Technology 16, 2637-2642. https://doi.org/10.1007/s13762-018-1839-z

Ravindra, U., 2015, 'Social temperature sensing', Master's thesis, Delft University of Technology.

Ringstaff, M., 2021, 'The 10 virtues of a proverbs 31 woman', A Virtuous Woman, viewed n.d., from https://avirtuouswoman.org/10-virtues-of-the-proverbs-31-woman/.

Ruiz-Cantero, M.T., Vives-Cases, C., Artazcoz, L., Delgado, A., Calvente, M.D.M.G. Miqueo, C. et al., 2007, 'A framework to analyse gender bias in epidemiological research', Journal of Epidemiology \& Community Health 61, ii46-ii53. https://doi. org/10.1136/jech.2007.062034

Schweiker, M., Fuchs, X., Becker, S., Shukuya, M., Dovjak, M., Hawighorst, M. et al., 2017, 'Challenging the assumptions for thermal sensation scales', Building Research \& Information 45(5), 572-589. https://doi.org/10.1080/09613218.2016. 1183185

Sheridan, S.C. \& Dixon, P.G., 2017, 'Spatiotemporal trends in human vulnerability and adaptation to heat across the United States', Anthropocene 20, 61-73.

Sibani, C.M., 2017, 'Gender inequality and its challenge to women development in Nigeria: The religious approach', UJAH: Unizik Journal of Arts and Humanities 18 432-449. https://doi.org/10.4314/ujah.v18i2.25

Simone, A., Olesen, B.W., Stoops, J.L. \& Watkins, A.W., 2013, 'Thermal comfort in commercial kitchens (RP-1469): Procedure and physical measurements (part 1)', HVAC \& R Research 19, 1001-1015. https://doi.org/10.1080/10789669.20 13.840494

Singer, B.C. \& Stratton, J.C., 2014, Addressing kitchen contaminants for healthy lowenergy homes, U.S. Department of Energy, Office of Scientific and Technical Information: Lawrence Berkeley National Laboratories, Berkeley, CA. 
Singh, A., Kamal, R., Mudiam, M.K.R., Gupta, M.K., Satyanarayana, G.N.V., Bihari, V. et al., 2016, 'Heat and PAHs emissions in indoor kitchen air and its impact on
kidney dysfunctions among kitchen workers in Lucknow, North India', PLoS One 11(12), 1-16. https://doi.org/10.1371/journal.pone.0148641

Sümer, D., 2020, 'Effects of ergonomic risk parameters on gender', International Journal of Science and Engineering Investigations 102( 9), 80-87.

Totsky, L., 2006, Workplace heat hazards, viewed n.d, from www.michigan.gov > wsh_ heat_hazards_242049_7.

Troitino, C., 2020, Less than $7 \%$ of U.S restaurants are led by women - one director wants to change that, viewed n.d., from https://www.forbes.com/sites/ christinatroitino/2020/02/29/less-than-7-of-us-restaurants-are-led-by-womenone-director-wants-to-change-that/?sh=ad5b6a120603

Unison, 2014, Temperature at work, Health and Safety Information Sheet, Unison, London.

United Nations, 2014, The World Survey on the role of women in development, on the theme of "gender equality and sustainable development", viewed n.d., from https://sustainabledevelopment.un.org/content/documents/1900unwomen https://sustainabledevelopment.

United Nations, 2017, ESAP.Gender, the environment and sustainable development in Asia and the Pacific, viewed n.d., from https://www.unescap.org/sites/default/ Asia and the Pacific, viewed n.d., from https://www.
files/publications/SDD-Gender-Environment-report.pdf.

University of Birmingham Health and Safety Fact File, 2006, Temperature, humidity, ventilation and lighting in the workplace, viewed n.d., from https://intranet. birmingham.ac.uk/hr/documents/public/hsu/information/workplaces/ workplaceconditions.pdf.
University of North Carolina, 2021, Ergonomics, viewed n.d, from https://ehs.unc. edu/workplace-safety/ergonomics/.

Van Hoof, J., Schellen, L., Soebarto, V., Wong, J. \& Kazak, J., 2017, 'Ten questions concerning thermal comfort and ageing', Building and Environment 120, 123-133. https://doi.org/10.1016/j.buildenv.2017.05.008

Wong, T.W., Wong, A.H., Lee, F.S. \& Qiu, H., 2011, 'Respiratory health and lung function in Chinese restaurant kitchen workers', Occupational and Environmental Medicine 68(10), 746-752. https://doi.org/10.1136/oem.2010.059378

World Health Organization, 2020, Behaviour change campaigns. Principle: Actionable, Environmental Protection Agency, Washington, DC.

Xiang, J., Bi, P., Pisaniello, D. \& Hansen, A., 2014, 'Health impacts of workplace heat exposure: An epidemiological review', Industrial Health 52(1), 91-101. https:// doi.org/10.2486/indhealth.2012-0145

Yasuoka, A., Kubo, H., Tsuzuki, K. \& Isoda, N., 2015, Gender differences in thermal comfort and responses to skin cooling by air conditioners in the Japanese summer', Journal of the Human-Environment System 18, 11-20.

Zhang, F. \& De Dear, R., 2019, 'Impacts of demographic, contextual and interaction effects on thermal sensation - Evidence from a global database', Building and Environment 162, 106286. https://doi.org/10.1016/j.buildenv.2019.106286

Zhao, Y. \& Zhao, B., 2018, 'Emissions of air pollutants from Chinese cooking: A literature review', Building Simulation 11, 977-995. https://doi.org/10.1007/ s12273-018-0456-6

Zippia, Fast food worker, viewed n.d., from https://www.zippia.com/fast-foodworker-jobs/demographics/. 